\title{
Distribution of phytoplankton in some parts of Lagos Lagoon, Southwest Nigeria
}

\author{
A. S. YAKUB*, K. J. BALOGUN, G. E. AJANI, K.O. RENNER, A. A. ARIYO, \\ B. O. BELLO, J. A. NKWOJI and J. K. IGBO
}

Nigerian Institute for Oceanography and Marine Research, Lagos, Nigeria

*Corresponding author; E-mail: demolaniomr@yahoo.com;

\begin{abstract}
Investigations were carried out on spatial and seasonal composition and distributions of phytoplankton in some parts of the Lagos Lagoon. Phytoplankton samples were collected from twelve stations during the wet (July, 2008) and dry (March, 2009) seasons. A typical freshwater condition prevailed in the study area during wet season with salinity of 0 parts per thousand $(\%$ oo $)$ at every station, whereas during the dry season, relatively high salinity levels were recorded from all the stations with decreasing trend toward the river mouth. The two seasons had the diatoms (Bacillariophytes) of the Orders Centrales and Pennales as the dominant phytoplankton taxa. A total of 2896 phytoplankton belonging to twenty-seven species, eight orders and four classes were recorded during wet season while the dry season had a total of 1550 phytoplankton, which cut across sixteen species, three orders and two classes. Wet and dry seasons respectively had Aulacoseira granulata and Coscinodiscus sps. as the dominant phytoplankton taxa. Higher dominance (0.33) and Margalef diversity (3.26) but lower Shanon-Wiener diversity (1.94) and evenness of distribution (0.26) indices were recorded during the wet than dry seasons. The findings show the influence of seasonality on phytoplankton composition and distributions in the Lagos Lagoon and suggest relatively stress-free environmental conditions within the study area.

(C) 2011 International Formulae Group. All rights reserved.
\end{abstract}

Keywords: Phytoplankton, Composition, Distribution, Season, Salinity.

\section{INTRODUCTION}

Phytoplankton community constitutes a major group of primary producers in aquatic ecosystem. The array of phytoplankton community in a water body is a reflection of its level of productivity (Erondu and Chindah, 1991; Ama-Abasi and Akpan, 2006; Saliu and Ekpo, 2006).

Indeed, the phytoplankton community structures highly depend on the nutrient concentrations in the water body. As a result of this, the level of anthropogenic enrichment of a water body with nutrients strongly influences its phytoplankton spectrum in terms of the composition, distribution and abundance. Thus they are good biomonitoring candidates for assessing the health status of an aquatic environment (Yakub, 2004; Onyema and Nwankwo, 2009). Also, the spatio-temporal distribution of 
phytoplankton can give an indication of variations of salinity especially in estuarine or brackish water environment (Ama-Abasi and Akpan, 2005).

Lagos Lagoon is the largest of the four lagoon systems of the Gulf of Guinea. Apart from supporting tremendous artisanal fishing of the capture fisheries sector, it provides necessary ecological habitats such as breeding and nursery grounds for a vast number of both freshwater and marine macrofauna species. Previous studies of anthropogenic wastes and environmental modifications in the Lagos lagoon have revealed increased levels of pollution stress in the water body (Ajao, 1996; Edokpayi and Nkwoji, 2007; Onyema and Nkwoji, 2009; Emmanuel et al., 2010). The enrichment of the water body with high level of biodegradable matter, nutrients, toxic and other land-based substances could upset the natural ecological equilibrium, therefore distorting biodiversity (Nwankwo and Akinsoji, 1992; Emmanuel et al., 2010).

Meanwhile, compared with the inland freshwater body counterparts in the southwestern Nigeria, information dealing with the plankton species of the Lagos lagoon and its environs is relatively scanty. This paper therefore reports on the investigation carried out on spatial and seasonal variations in phytoplankton flora in some selected stations in the Lagos Lagoon.

\section{MATERIALS AND METHODS}

\section{The study area}

The Lagos lagoon (Fig. 1) is located in Lagos State, Nigeria and is one of the nine lagoons in South-western Nigeria. The Lagos lagoon, Nigeria (Fig. 1) is an open, shallow and tidal lagoon, with a surface area of 208 $\mathrm{km}^{2}$ (FAO, 1969) and an average depth of less than two meters. It provides the only natural opening to the sea for the nine lagoons of South Western Nigeria.

Lagos Lagoon has tropical climatic conditions with rainy season from April through November and dry season from
December through March. Owing to the dynamics of river inflow and seawater incursion, the lagoon experiences brackish condition that is more discernable in the dry season. In the rainy season, the increased river inflow creates freshwater and low brackish conditions in various parts of the lagoon.

A total of twelve stations (1-12) were selected within the Lagos Lagoon for the study. The stations cut across Queen's Drive (station 1) and Park view (station 2) in Ikoyi through the mid-lagoon (station 6) to Majidun (station 12) at the mouth of Ogun River (Fig. 1). The entire study area lies within latitude $6^{0}$ 12 ' $\mathrm{N}$ and $6^{0} 22$ ' $\mathrm{N}$ and longitude $3^{0} 16^{\prime \prime} \mathrm{E}$ and $3^{0} 30^{\prime}$ 'E (Fig. 1). Sampling was carried out at each station both in the rainy (July 2008) and dry (March 2009) seasons.

\section{Collection and analysis of water samples}

Surface water samples were collected with $1 \mathrm{dm} 3$ water samplers and stored in 1litre water bottles and analysed in the laboratory for $\mathrm{pH}$, conductivity, salinity and turbidity using a multi-meter water checker (Horiba U12). Water sample was collected in $250 \mathrm{ml}$ dissolved oxygen bottle and fixed with Winkler solution at each station. This was followed by dissolved oxygen estimation using Iodometric Winkler's method. Air and surface water temperature were measured in situ using mercury-in-glass thermometers. Alkalinity of the water samples was determined by titrating dilute $\mathrm{HCl}$ against 50 $\mathrm{ml}$ of the water sample using methyl orange as an indicator.

\section{Collection and analysis of plankton samples}

Phytoplankton sample was collected on each occasion with a $55 \mu \mathrm{m}$ mesh size standard plankton net held against the current of the ebbing tide for 10 mins. The net was then hauled in and the sample transferred to a $250 \mathrm{ml}$ labelled plastic container with screw cap and preserved with $4 \%$ unbuffered formalin and stored in the laboratory prior to microscopic analysis. 
In the laboratory, five drops (using a dropper) of the concentrated sample $(10 \mathrm{ml})$ was investigated at different magnifications (50X, 100X and 400X) using a Wild II binocular microscope with calibrated eyepiece and the average recorded. A suitable plankton sample mount was then created. The drop count microscope analysis method described by Onyema (2007) was used to estimate the phytoplankton abundance. Appropriate texts such as Vanlandingham (1982) Nwankwo (1990, 1995, 2004), Bettrons and Castrejon (1999), Siver (2003) and Rosowski (2003) were used for the identification of the phytoplankton.

\section{Plankton community structure analysis}

During each season, diversity (total number of phytoplankton taxa) and total abundance of phytoplankton for every station were determined using data from identification and counting.

The composition, distribution and abundance of phytoplankton of the entire study area were determined for each season by pooling the data for all the stations. Diversity indices: Simpson's Dominance (C), Margalef species richness (d) diversity and Shannon Wiener (H) of the entire study area were computed for each season as described by Ogbeibu (2005) using a computer software package, 'Past' by Hammer and Harper (2005).

\section{RESULTS}

\section{Physico-chemical parameters}

The physicochemical parameters recorded at the twelve stations during rainy and dry seasons are presented in Table 1. While zero salinity level was recorded at every station during the rainy season, the dry season had salinity range of $11.40 \%$ at station 11 to $30.50 \%$ at station 2 (Table 1 ). In the same vein, generally low conductivity levels were recorded from all stations during rainy season, whereas relatively high levels, which ranged from $19.50 \mathrm{mScm}^{-1}$ at station 11 to $46.50 \mathrm{mScm}^{-1}$ at station 2 were obtained in the dry season (Table 1). On the other hand, every station had higher turbidity, $\mathrm{pH}$ and DO levels during rainy than dry season (Table 1).

\section{Phytoplankton}

The Phytoplankton community of the study area had the diatoms (Bacillariophytes) as the dominant taxa both in rainy and dry seasons. The diatoms belonged mainly to the Orders Centrales and Pennales. The spatial distributions, abundance and diversity of phytoplankton within the study area during the rainy and dry seasons are respectively presented in Tables 2 and 3. In the rainy season, Aulacoseira granulata which constituted the most dominant phytoplankton taxon, was distributed through the twelve stations and had its highest abundance both at stations 11 and 12 (Table 2). Other phytoplankton taxa encountered during the rainy season were Cyanophytes (six taxa), Chlorophytes (five taxa) and Euglenophytes (four taxa). The total number of phytoplankton taxa during the rainy season ranged from five at stations 2 and 7 to twentyfive at station 12 (Table 2). Total Phytoplankton abundance during rainy season ranged from 85 at station 5 to 895 at station 12 (Table 2).

During dry season, Coscinodiscus centralis had the widest distribution with occurrence at every station except stations 1 and 4 (Table 3). Apart from the diatoms, Oscillatoria limnosa, a Cyanophyte was the only phytoplankton encountered during the dry season (Table 3). During the dry season, total number of phytoplankton taxa varied from one at station 4 to eleven at station 7 while total abundance ranged from ten at station 4 to 385 at station 2 (Table 3).

On a general note, 2,896 specimens of phytoplankton which belonged to twentyseven species, eight orders and four classes were collected from the entire study area during the rainy season. Aulacoseira granulata was the dominant species and had its occurrence only during the rainy season 
(Table 4). On the other hand, Coscinodiscus constituted the dominant phytoplankton taxa during dry season (Table 4). During the dry season, total Phytoplankton abundance of 1550, which cut across sixteen species, three orders and two classes were recorded (Table 4). Higher dominance (0.33) and Margalef diversity (3.26) but lower Shannon-Wiener diversity (1.94) and evenness of distribution (0.26) indices were recorded from the study area during the rainy than dry seasons (Table 4). The diatoms (Baccillariophytes), which constituted the dominant phytoplankton class, had higher representations during the dry than the rainy seasons.

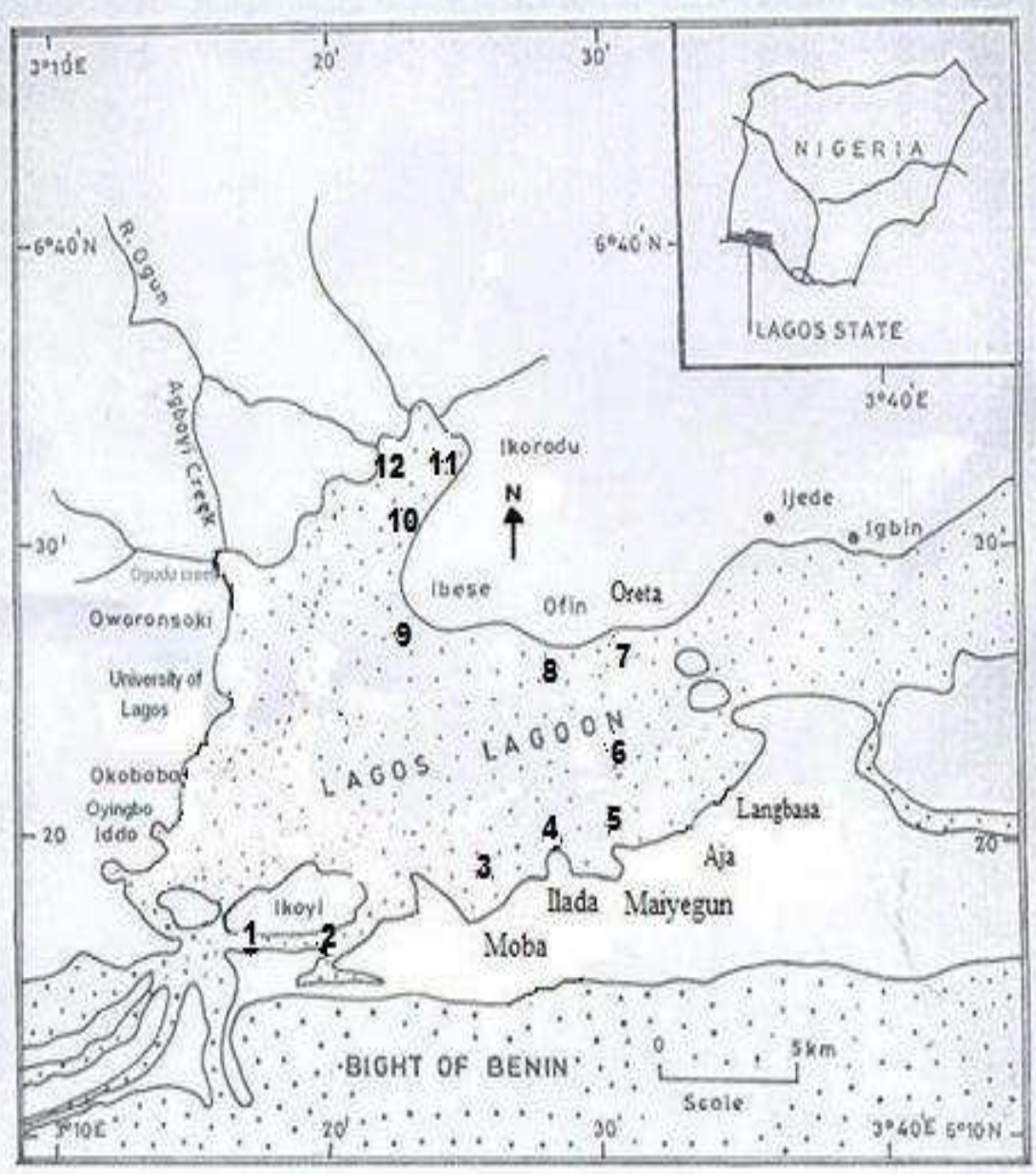

Figure 1: Map of study area showing the sampling sites. 
A. S. YAKUB et al. /Int. J. Biol. Chem. Sci. 5(1): 150-163, 2011

Table 1: Spatial and seasonal distributions of the physico-chemical parameters in some parts of Lagos Lagoon.

\begin{tabular}{|c|c|c|c|c|c|c|c|c|c|c|c|c|}
\hline \multirow[t]{2}{*}{ Station } & \multicolumn{2}{|c|}{ WT $\left({ }^{\circ} \mathrm{C}\right)$} & \multicolumn{2}{|c|}{ pH } & \multicolumn{2}{|c|}{ Cond. $\left(\mathrm{mScm}^{-1}\right)$} & \multicolumn{2}{|c|}{ Turb. (NTU) } & \multicolumn{2}{|c|}{ Sal. (ppt) } & \multicolumn{2}{|c|}{ DO $(\mathrm{Mg} / \mathrm{l})$} \\
\hline & $\mathbf{R S}$ & DS & RS & DS & RS & DS & RS & DS & $\mathbf{R S}$ & DS & RS & DS \\
\hline 1 & 29 & 28 & 9.1 & 8.1 & 0.84 & 46 & 78 & 10 & 0 & 29.9 & 11.2 & 8.00 \\
\hline 2 & 29 & 27 & 8.9 & 8 & 1.0 & 46.5 & 366 & 10 & 0 & 30.5 & 13.6 & 13.2 \\
\hline 3 & 28 & 28.5 & 9 & 8.1 & 0.64 & 45.8 & 126 & 10 & 0 & 29.8 & 18.4 & 10.0 \\
\hline 4 & 28 & 28.5 & 9.1 & 7.9 & 0.67 & 34.7 & 108 & 10 & 0 & 22.0 & 15.6 & 14.80 \\
\hline 5 & 28.9 & 29 & 8.9 & 7.5 & 0.61 & 32.2 & 208 & 147 & 0 & 20.0 & 12.0 & 7.20 \\
\hline 6 & 29 & 29.5 & 8.8 & 6.8 & 0.12 & 32.5 & 226 & 135 & 0 & 20.4 & 11.2 & 11.6 \\
\hline 7 & 29 & 29 & 9.2 & 6.8 & 0.19 & 29.0 & 86 & 10 & 0 & 17.8 & 12.4 & 8.4 \\
\hline 8 & 29 & 29 & 8.9 & 6.7 & 0.3 & 29.0 & 386 & 100 & 0 & 17.9 & 12.4 & 10.4 \\
\hline 9 & 29.5 & 29 & 9 & 7.5 & 0.24 & 28.9 & 248 & 101 & 0 & 17.8 & 13.2 & 12.8 \\
\hline 10 & 28 & 28.5 & 9 & 6.6 & 0.54 & 22.4 & 256 & 107 & 0 & 13.4 & 9.6 & 9.2 \\
\hline 11 & 28 & 29.5 & 8.8 & 6.6 & 0.18 & 19.5 & 346 & 109 & 0 & 11.4 & 10.4 & 8.0 \\
\hline 12 & 28 & 29.5 & 9.1 & 6.7 & 0.61 & 19.8 & 276 & 10 & 0 & 11.7 & 8.4 & 5.6 \\
\hline
\end{tabular}

DS: Dry season

Table 2: Spatial Distribution of Phytoplankton in some part of Lagos Lagoon in the rainy season (July, 2008).

\begin{tabular}{|c|c|c|c|c|c|c|c|c|c|c|c|c|}
\hline & \multicolumn{8}{|c|}{ Stations } & \multirow[b]{2}{*}{9} & \multirow[b]{2}{*}{10} & \multirow[b]{2}{*}{11} & \multirow[b]{2}{*}{12} \\
\hline & 1 & 2 & 3 & 4 & 5 & 6 & 7 & 8 & & & & \\
\hline $\begin{array}{l}\text { Phytopankton taxa } \\
\text { Class - Bacillariophyta } \\
\text { Order I - Centrales }\end{array}$ & & & & & & & & & & & & \\
\hline $\begin{array}{l}\text { Actinoptychus splendens Ehrenberg } \\
\text { Aulacoseira granulata Ehrenberg (Ralfs) }\end{array}$ & $\begin{array}{c}20 \\
10\end{array}$ & $\begin{array}{c}25 \\
20\end{array}$ & $\overline{70}$ & $\begin{array}{c}5 \\
35\end{array}$ & - & $\begin{array}{l}5 \\
20\end{array}$ & - & $\begin{array}{c}10 \\
75\end{array}$ & $\begin{array}{r}5 \\
55\end{array}$ & $\begin{array}{l}5 \\
20\end{array}$ & $\begin{array}{l}15 \\
75\end{array}$ & $\begin{array}{l}30 \\
105\end{array}$ \\
\hline
\end{tabular}


A. S. YAKUB et al. / Int. J. Biol. Chem. Sci. 5(1): 150-163, 2011

Aulacoseira granulata var. angustissima Muller Aulacoseira granulata var. curvata Simon Coscinodiscus eccentrius Ehrenberg

Cyclotella menighiniana Kutzing

Cyclotella striata (Kutzing) Grunow

Terpsinoe musica (Ehr) Hustedt

Order II - Pennales

Gyrosigma balticum (Her.) Rabenhorst

Navicula mutica Kutzing

Pinnularia major (Kutzing) Rabenh

Pleurosigma angulatum (Quekett)

Surirella splendida Wm. Smith

Synedra crystalline (Ag) Kutzing

Synedra Synedra Sp.

Synedra ulna (Nitzsch) Ehrenberg

Class- Cyanophyta

Order I - Chroococcales

Microcystis flos-aquae Kirchner

Order II - Hormogonales

Oscillatoria chalybea Gomont

Oscillatoria curviceps C.A. Agardh

Oscillatoria limnosa Agardh

Oscillatoria tenius Agardh

Spirulina platensis Geitler

\section{Class-Chlorophyta}

Order I - Ulothricales

Spirogyra africana Fritsch Cruda

Spirogyra sp.

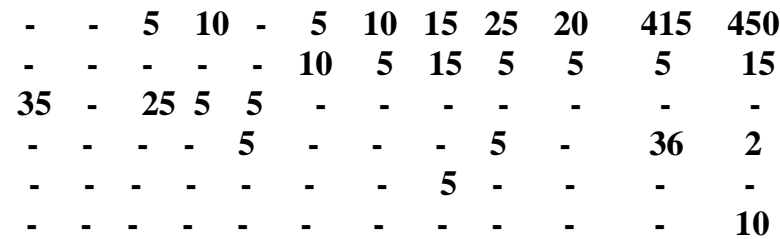

$\begin{array}{llllllllllll}15 & 10 & 25 & 5 & - & 10 & - & - & - & - & - & -\end{array}$

$\begin{array}{llllllllllll}- & - & - & - & - & - & - & - & - & - & - & 15 \\ - & - & - & - & - & - & - & 5 & - & 15 & - & 5\end{array}$

\begin{tabular}{llllllllllll}
25 & 15 & 10 & - & 5 & - & - & 5 & - & 15 & - & 5 \\
\hline
\end{tabular}

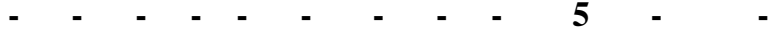

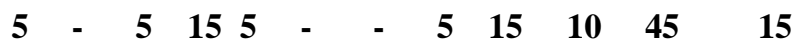

$\begin{array}{llllllllllll} & - & - & - & - & - & - & - & - & - & - & 10\end{array}$

$-\quad-\quad-\quad-10-\quad-5 \quad-515$

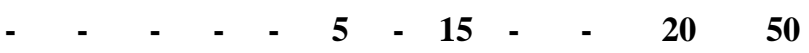

$\begin{array}{rrrrrrrrrrrr}- & - & - & - & - & - & - & - & 5 & 25 & - & - \\ - & - & - & - & - & - & - & - & - & \mathbf{1 5} & \mathbf{1 5} & \mathbf{1 5} \\ 15 & 5 & 5 & - & 10 & - & 5 & - & - & 5 & 5 & 5 \\ - & - & - & - & - & 5 & - & - & \mathbf{1 5} & - & 5 & - \\ - & - & - & - & - & - & - & - & - & - & - & 15\end{array}$ 
Table 2 (Contn).

\begin{tabular}{|c|c|c|c|c|c|c|c|c|c|c|c|c|c|}
\hline & & \multicolumn{8}{|c|}{ Stations } & \multirow[b]{2}{*}{9} & \multirow[b]{2}{*}{10} & \multirow[b]{2}{*}{11} & \multirow[b]{2}{*}{12} \\
\hline & & 1 & 2 & 3 & \multirow[t]{2}{*}{4} & \multirow[t]{2}{*}{5} & \multirow[t]{2}{*}{6} & \multirow[t]{2}{*}{7} & \multirow[t]{2}{*}{8} & & & & \\
\hline Phytopankton taxa & & & & & & & & & & & & & \\
\hline Order II - Zygnematales & & & & & & & & & & & & & \\
\hline Closterium ehrenbergii Meneghini & & - & - & - & - & - & - & - & - & 5 & 25 & 35 & 30 \\
\hline Closterium moniliferum (Bory.) Ehrenb. & & - & - & - & - & - & - & - & - & - & 5 & - & 5 \\
\hline Gonatozygon sp. & & - & - & - & 25 & 5 & 55 & 35 & 50 & - & 10 & - & 25 \\
\hline Order III - Cladophorales & & & & & & & & & & & & & \\
\hline Cladophora glomerata (L) Kutzing & & - & - & - & - & - & - & - & - & - & 5 & - & 25 \\
\hline Class - Euglenophyta & & & & & & & & & & & & & \\
\hline Order - Euglenales & & & & & & & & & & & & & \\
\hline Euglena acus Ehrenberg & & - & - & - & - & - & - & - & - & - & 30 & - & 5 \\
\hline Phacus acuminatus Stokes & & - & - & - & - & - & - & - & 5 & - & - & - & 5 \\
\hline Trachelomonas hispida (Perry) Stein & & - & - & - & - & - & - & - & - & - & - & 5 & 5 \\
\hline Total species diversity (S) & 7 & 5 & 7 & 7 & 7 & 9 & 5 & 11 & 10 & 16 & 13 & 25 & \\
\hline Total phytoplankton abundance $(\mathbf{N})$ & 125 & 110 & 145 & 100 & 8512 & 25 & 135 & 205 & 140 & 215 & 670 & 895 & \\
\hline
\end{tabular}


A. S. YAKUB et al. /Int. J. Biol. Chem. Sci. 5(1): 150-163, 2011

Table 3: Spatial distribution of phytoplankton in some part of Lagos Lagoon in the dry season (March, 2009).

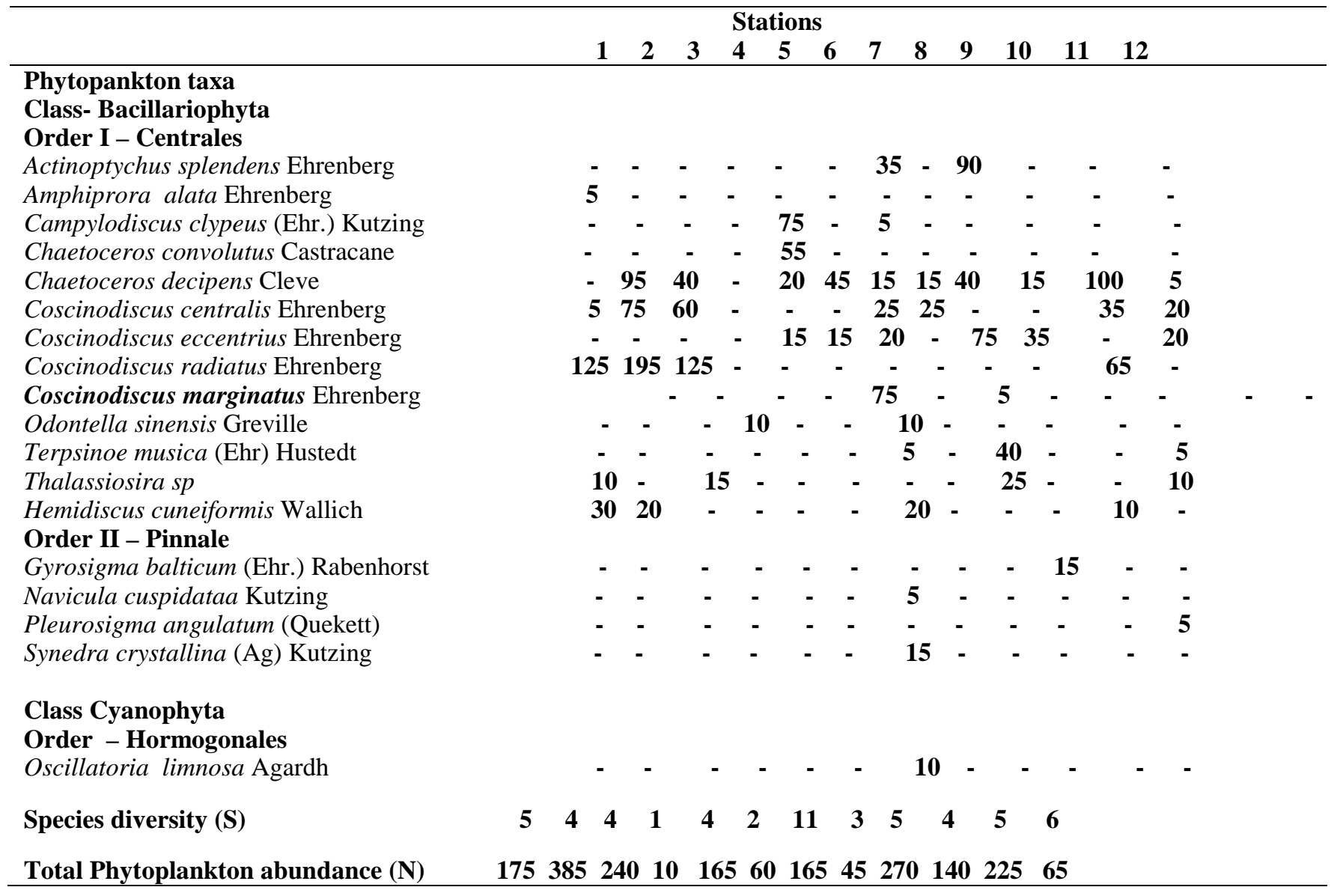


A. S. YAKUB et al. /Int. J. Biol. Chem. Sci. 5(1): 150-163, 2011

Table 4: Seasonal compositions, distributions and diversity of phytoplankton in the study area.

\begin{tabular}{lcr}
\hline TAXA & \multicolumn{2}{c}{ ABUNDANCE } \\
\hline \multicolumn{4}{c}{$\begin{array}{c}\text { Class I:- Bacillariophyta } \\
\text { Order I - Centrales }\end{array}$} & Dry Season \\
Actinoptychus splendens & $\mathbf{1 2 0}$ & $\mathbf{1 2 5}$ \\
Amphiprora alata & -- & $\mathbf{5}$ \\
Aulacoseira granulate & $\mathbf{1 6 3 0}$ & -- \\
Campylodiscus clypeus & -- & $\mathbf{8 0}$ \\
Chaetoceros convolutes & -- & $\mathbf{8 0}$ \\
Chaetoceros decipens & -- & $\mathbf{5 5}$ \\
Coscinodiscus centralis & -- & $\mathbf{1 9 0}$ \\
Coscinodiscus eccentrius & $\mathbf{7 0}$ & $\mathbf{1 9 0}$ \\
Coscinodiscus radiatus & -- & $\mathbf{1 6 0}$ \\
Coscinodiscus marginatus & -- & $\mathbf{4 4 5}$ \\
Cyclotella menighiniana & $\mathbf{1 5}$ & - \\
Cyclotella striata & $\mathbf{5}$ & - \\
Hemidiscus cuneiformis & -- & $\mathbf{7 0}$ \\
Odontella sinensis & -- & $\mathbf{2 0}$ \\
Terpsinoe musica & $\mathbf{1 0}$ & $\mathbf{4 5}$ \\
Thalassiosira sp & -- & $\mathbf{5 0}$ \\
Gyrosigma balticum & & $\mathbf{1 5}$ \\
Navicula cuspidataa & $\mathbf{6 5}$ & $\mathbf{5}$ \\
Navicula mutica & -- & $\mathbf{- -}$ \\
\hline
\end{tabular}


A. S. YAKUB et al. /Int. J. Biol. Chem. Sci. 5(1): 150-163, 2011

Pinnularia major

Pleurosigma angulatum

25

Surirella splendida

Synedra crystalline

Synedra ulna

Synedra sp.

Class II-: Cyanophyta

Order I- Chroococcales:

Microcystis flos-aquae

Order II - Hormogonales:

Oscillatoria chalybea

Oscillatoria curviceps

Oscillatoria limnosa

Table 4 Contn.

$$
\text { Taxa }
$$

Phytopankton taxa

Oscillatoria tenius

Spirulina platensis

Class III:- Chlorophyta

Order I- Ulothricales:

Spirogyra Africana

Order II- Zignematales:

Closterium ehrenbergii

Closterium moniliferum

\begin{tabular}{cc}
\multicolumn{2}{c}{ Abundance } \\
Rainy Season & Dry Season \\
25 & -- \\
15 & -- \\
& \\
40 & \\
95 & -- \\
10 & -- \\
&
\end{tabular}


A. S. YAKUB et al. /Int. J. Biol. Chem. Sci. 5(1): 150-163, 2011

Gonatozygon sp.

Order III- Cladophorales:

Cladophora glomerata

Class IV:- Euglenophyta

Order Euglenales:

Euglena acus

Phacus acuminatus

Trachelomonas hispida

Total number of Taxa

Total abundance

Dominance

Margalef diversity

Shanon-Wiener diversity
205

30

35

10

10

27

2,896

0.331

3.362

1.939
$-$

$\mathbf{1 , 5 5 0}$

0.141

2.042

2.271 


\section{DISCUSSION}

The seasonal variations in physicochemical parameters indicate the great influence rainfall has on the physico-chemical hydrology of tropical waters (Adebisi, 1981; Okogwu and Ugwumba, 2006; Onyema 2009). The freshwater condition was indicated by zero salinity level at every station during wet season while a typical estuarine salinity condition was recorded during dry season showing the effect of rainfall on the salinity profile of the Lagos Lagoon. The rains could have had dilution effect on the Lagoon water as well as increased the level of freshwater discharge from the river basins into the Lagoon. The decreasing trend in salinity towards Ogun River mouth observed during dry season shows that saline water intrusion from the Atlantic Ocean was responsible for the relatively high salinity of the Lagos Lagoon during the season.

The relatively low conductivity levels recorded during wet season could also be attributed to the dilution effect of the rains during the season. This as well as the similarity in salinity and conductivity variation patterns during dry season, indicates that ionic salts accounts mostly for conductivity of the Lagos Lagoon (Ogunwenmo and Osuala, 2004; Edokpayi and Nkwoji, 2007; Onyema and Nkwoji, 2009). The relatively high turbidity of the wet season could be attributed to high level of particulate matters brought into the lagoon from surface run-offs by flood during the season. Relatively high DO levels during the wet season could be as a result of high water current and turbulence that characterise the season (Adebisi, 1981).

The species composition of phytoplankton recorded in this study corroborates the earlier findings of Nwankwo (1996) in the Lagos Lagoon. The author listed Coscinodiscus, Aulacoseira, Bacillaria, Odontella, Gomphosphaeria, Paralia, Desmidium, and Microcystis as the possible prevalent phytoplankton genera in the Lagos
Lagoon. The relatively similar phytoplankton species composition of all stations during wet season could be as a result of the freshwater condition observed at all the stations. The predominance of phytoplankton community by diatoms (Centralles and Pennales) in this study conforms to earlier findings in Nigerian water bodies (Eroundu and Chindah, 1991; Ama-Abasi and Akpan, 2006; Abowei et al. 2008; Onyema, 2008). The occurrence of Aulacoseira granulata as the dominant diatom, especially during wet season had been reported earlier by Onyema (2008) in Iyagbe Lagoon. The author however recorded more Pennalle than Centric diatoms, which was attributed to the effect of tidal mixing that probably scours up phytobenthic forms into plankton in Iyagbe Lagoon.

Contrary to the findings in this study, Salisu and Ekpo, 2006 recorded pollution tolerant blue green algae (Cyanophytes) as the dominant phytoplankton taxa from Ogbe Creek, Lagos. The author attributed this to human anthropogenic activities in the creek. Yakub (2004) also reported the blue-greens as the dominant taxa at an organically polluted point of Awba Stream, Ibadan, western Nigeria. Perhaps, the diatoms (Bacillariophytes), which constituted the dominant phytoplankton taxa in the present study are relatively pollution sensitive (Yakub, 2004; Ama-Abasi and Akpan, 2006; Onyema, 2008).

Higher diversity recorded within the diatoms during dry than rainy season conforms with the findings of Eroundu and Chindah (1991) in New Calabar River and Onyema (2008) in Iyagbe Lagoon. The lower Shanon-Wiener diversity despite the higher species number and Margalef diversity level recorded during rainy than dry season was as a result of the occurrence of Aulacoseira granulata with much higher abundance than other taxa. While Margalef index only measures species richness, Shanon-Wiener evaluates both species richness and evenness 
of distributions of total individuals among different species or taxa (Ogbeibu, 2005).

The dominance of Phytoplankton by Aulacoseira during rainy season while the dry season had Coscinodiscus as the dominant genus indicate a marked seasonal variation in phytoplankton composition and distribution within the study area of the Lagos Lagoon. Similar to this, Ama-Abasi and Akpan (2006) reported seasonal variation in distribution and succession of phytoplankton of the Cross River Estuary, Southeast Nigeria. The author reported a clear succession of Skeletonema cosmatum in dry season by Melosira granulata in rainy season and attributed it to seasonal changes in salinity and nutrient profiles of the water body.

The higher phytoplankton abundance and species richness recorded during rainy than dry season could be attributed to influx of allochtonous nutrients as the river drains into the Lagoon. The high level of allochtonous nutrients could have promoted phytoplankton production during the rainy than dry season. Furthermore, the relatively higher phytoplankton abundance and species richness at the stations close to river mouth (stations 8-12) especially during the wet season could be as a result of higher nutrient level at the stations than those far from the river mouth. The relatively high phytoplankton abundance recorded in the wet season agrees with the finding of Ama-Abasi and Akpan (2006) in the Cross River Estuary.

The findings in this study show the influence of seasonality on the physicochemical properties especially the salinity and nutrient profiles, which in turn determine phytoplankton composition and distribution in the Lagos Lagoon. The predominance of phytoplankton community of the study area both in wet and dry seasons by diatoms as against the pollution tolerant blue-green and green algae, could be an indication of relatively low level of human anthropogenic activities within this part of the Lagos Lagoon.

\section{REFERENCES}

Abowei JFN, Davis OA, Tawari CC. 2008. Phytoplankton in the lower Sombreiro River, Niger Delta, Nigera. Research Journal of Biological Sciences, 3(12): 1430-1436.

Adebisi AA. 1981. The physico-chemical hydrology of a tropical seasonal river Upper Ogun River. Hydrobiologia. 79: $157-165$.

Ajao EA, Fagade SO. 1991. Study of the sediments and communities in Lagos lagoon, Nigeria. Oil and Chemical Pollution. Elsevier Science Publishers Ltd., England.

Ama-Abasi D, Akpan FR. 2006. Possible Bioindicators of salinity change in Cross River Estuary, Southeast Nigeria. In Proceedings of the $20^{\text {th }}$ Annual Conference of the Fisheries Society of Nigeria $\left(14^{\text {th }}-18^{\text {th }}\right.$ November). Ansa EJ, Anyanwu PE, Ayonadu BW, Erondu ES, Deekae SN (eds). Port Harcourt: Nigeria; 254-260.

Edokpayi CA, Nkwoji JA. 2007. Annual changes in the physico-chemical and macrobenthic invertebrate characteristics of the Lagos lagoon sewage dump site at Iddo, Southern Nigeria. Ecol. Env. \& Cons., 13(1): 13-18.

Emmanuel BE, Chukwu LO, Bakare SO. 2010. Hydro-chemistry, macroinvertebrate fauna and fish production of Acadja fishing site in a Tropical Lagoon Ecosystem. Journal of American Science, 61: 42-48.

Erondu ES, Chindah AC. 1991. Variations in some physico-chemical parameters and Phytoplankton of the New Calabar River at Aluu, Rivers State, Nig. Institute For Oceanography And Marine Research Tech. Paper. No. 75.

F.A.O. 1969. Fisheries Survey in the Western and mid-Western Regions of Nigeria. FAO/sf.74/NIR6. 142pp. 
Hammer Ø, Harper DAT, Ryan PD. 2001. Past: Palaeontogical Statistics Software packages for education and data analysis. Palaeontologia Electronica, 4(1): 9.

Nwankwo DI. 1998. The influence of sawmill wood wastes on diatom population at Oko-baba, Lagos, Nigeria. Nigerian Journal of Botany, 11: 15 - 24.

Nwankwo DI, Akinsoji A. 1992. Epiphyte community on water hyacinth Eichhornia crassipes in coastal waters of southwestern Nigeria. Arch. Hydrobiol., 124(4): $501-511$.

Ogamba EN, Chindah AC, Ekweozor IKE, Daka ER, Onwuteaka J, Bawo D. 2005. Impact of human activities on plankton of the Niger Delta Nigeria. Niger Delta Biologia, 5(1): 1-9.

Ogbeibu AE. 2005. Biostatics: A Practical Approach to Research Data Handling. Mindex Publishing Company Ltd; 15362.

Ogunwenmo CA, Osuala IA. 2004. Physicochemical parameters and macrobenthos of an estuarine creek and artificial pond in
Lagos, Southwestern Nigeria. Acta SATECH, 1(2): 128-132.

Okogwu OI, Ugwumba OA. 2006. The Zooplankton and environmental characteristics of Ologe Lagoon, Southwest, Nigeria. The Zoologist, 4: 8691.

Onyema IC. 2008. A checklist of phytoplankton species of Iyagbe Lagoon, Lagos. Journal of Fisheries and Aquatic Sciences, 3(3): 167-175.

Onyema IC, Nwankwo DI. 2009. Chlorophyll a dynamics and 'environmental factors in a tropical estuarine lagoon. Academia Arena, 1(1): 18 - 30 .

Yakub AS. 2004. Assessment of water quality and plankton of effluents receiving AwbaStream and Reservoir in Ibadan, Nigeria. African Journal of Applied Zoology and Environmental Biology, 6: 107-110. 